AJH

ISSN : 0973-4767
THE ASIAN JOURNALOF HORTICULTURE

Volume 15 | Issue 2 | December, 2020|34-38
Article history : Received : 24.08 .2020 Revised : 09.11.2020 Accepted : 18.11 .2020

\section{Effect of N.P.K. on plant growth, spike yield and flower quality of golden rod (Salidago canadensis) L. c.v. GOLDEN GATE}

\author{
A. Sai Bharath, S. Saravanan ${ }^{1}$ and B. Muralidharan ${ }^{1}$
}

\begin{abstract}
The present investigation was carried out during Rabi season 2019-2020 at experimental field, Department of Horticulture, Naini Agriculture Institute, Sam Higginbottom University of Agriculture, Technology and Sciences, Prayagraj (U.P.), India. The experiment was laid out in Randomized Block Design with three replications and 12 treatments of GOLDEN ROD (Salidago canadensis) L. C.v. GOLDEN GATE. T - N:P:K-75:85:70kg/ha, T - N:P:K75:100:75kg/ha, $\mathrm{T}_{3}$ - N:P:K-75:110:85kg/ha, $\mathrm{T}_{4}$ - N:P:K-75:120:90kg/ha, $\mathrm{T}_{5}$ - N:P:K-75:130:95kg/ha, $\mathrm{T}_{6}$ - N:P:K-75:135:100kg/ha, $\mathrm{T}_{7}$ - N:P:K-75:140:110kg/ha, $\mathrm{T}_{8}$ - N:P:K-85:145:115kg/ha, T $-\mathrm{N}: \mathrm{P}: \mathrm{K}-$ 100:150:120kg/ha, $\mathrm{T}_{10}-\mathrm{N}: \mathrm{P}: \mathrm{K}-110: 160: 125 \mathrm{~kg} / \mathrm{ha}, \mathrm{T}_{11}-\mathrm{N}: \mathrm{P}: \mathrm{K}-125: 170: 130 \mathrm{~kg} / \mathrm{ha}, \mathrm{T}_{12}-$ Control (water spray). Highest plant height $(130.3 \mathrm{~cm})$ and plant spread $(\mathrm{E}-\mathrm{W})(70.7 \mathrm{~cm})$ was obtained from $\mathrm{T}_{4}-$ $\mathrm{N}: \mathrm{P}: \mathrm{K}-75: 120: 90 \mathrm{~kg} / \mathrm{ha}$ where as highest plant spread $(\mathrm{N}-\mathrm{S})(67.27 \mathrm{~cm})$ was obtained from $\mathrm{T}_{1}$ $\mathrm{N}: \mathrm{P}: \mathrm{K}-75: 85: 70 \mathrm{~kg} / \mathrm{ha}$. Highest No. of stocks/plant (15.67), length of the stock $(44.13 \mathrm{~cm})$, weight of the stock $(56.1 \mathrm{~cm})$, no. of days for $50 \%$ flowering $(82.33)$ no. of days for $100 \%$ flowering (113.0) vase life when kept in water (10 days), vase life of stock when kept in $2 \%$ sugar solution (11.67 days) was obtained from $\mathrm{T}_{4}-\mathrm{N}: \mathrm{P}: \mathrm{K}-75: 120: 90 \mathrm{~kg} / \mathrm{ha}$ as it can be recommended treatment for farmers.
\end{abstract}

KEY WORDS : Golden rod, Nitrogen (N), Phosporous (P), Potassium (K)

Author for correspondence :

A. Sai Bharath

Department of Horticulture

Naini Agricultural Institute, SHUATS,

Prayagraj (U.P.) India

Email : bharathsai86@gmail.com

HOW TO CITE THIS ARTICLE : Sai Bharath, A., Saravanan, S. and Muralidharan, B. (2020). Effect of N.P.K. on plant growth, spike yield and flower quality of golden rod (Salidago canadensis) L. c.v. GOLDEN GATE. Asian J. Hort., 15(2) : 34-38, DOI : 10.15740/HAS/TAJH/15.2/34-38. Copyright@2020 : Hind Agri -Horticultural Society
$\mathrm{F}$ lowers have been an integral part of Indian culture, being used in social and religious functions, requirement of daily life or just a passion. These are also symbolize beauty, love and tranquility. Growing of flowers have been practiced in our country for many centuries as evidenced by the references found in ancient literature but commercial cultivation of flowers and development of floriculture as an industry are of recent origin (Singh and Sangama, 2000).

Our country is endowed with diverse agro-climatic conditions, which provides opportunities for production of all major flowers throughout the year. Yet earlier floriculture in our country was restricted to the growing of traditional flowers like marigold, jasmine, gaillardia, spider lily, chrysanthemum and rose. They are used as loose flowers. But today, realizing the importance of cut flowers at national and international levels, cultivation of high value cut flower crops such as Dutch rose, carnation, gladiolus, golden rod, gypsophila, gerbera, lilium etc. have been under taken. 
The world trade in flowers is estimated to about $\$ 50$ billion. Contribution from developed countries is higher in total world trade in floricultural products. Cut flowers contribute 45 per cent share of the total world trade in floricultural products (Singh and Sangama, 2000). In the global market, Netherlands, Germany, Japan, Europe, U.A.E and Hong Kong are the main markets for Indian flowers. International trade of flowers has greatly expanded.

Solidago, commonly known as golden rod, belongs to the family Asteraceae botanically known as Solidago canadensis L. The genus comprises about 130 species, mostly native of North America. Few species like Solidago canadensis, $S$. virgaurea, $S$. memoralis are grown in beds borders or rock garden. Besides, they are also used as cut flowers for indoor decoration and bouquets. It produces large panicles of yellow flowers for several months a year, which are very attractive cut flowers. These hardy perennial herbs grown in almost all types of climates and soils but prefer a sunny location.

Golden rod plant is medium in height (about 20-30 $\mathrm{cm}$ tall) and has light green leaves. Plant is spreading by producing (multiplying) new suckers. Golden rod requires about 100 to 130 days for coming in the flowering stage after planting. It bears panicles of about $50-75 \mathrm{~cm}$ of length with 30-50 numbers of inflorescence branches per panicle. The inflorescence of golden rod is very complex in nature. Basically each small head is about 1.0 to $1.2 \mathrm{~cm}$ in length and 0.5 to $0.7 \mathrm{~cm}$ in diameter and consists of about 8 to 10 disc florets and some ray florets. Heads are axillary, solitary on main axis as well as branches and on small branch let's forming a whole compound panicle with golden yellow inflorescence.

Golden rod is propagated by division of stools, from suckers or seeds. The plants are easy to grow. In moderate climate, planting can be done in any time but spring and rainy seasons are more favourable for growth (Sharma, 1989). The commercial cultivation of golden rod has not yet been exploited in India. Even though golden rod is cultivated in small scale by many farmers, there is also a great demand of golden rod panicles in large cities of India and greater scope exists for its export for various purposes like bouquets and table decoration.

Golden rod can be cultivated on all type of soils having good structure drainage with proper management practices. Among the different management practices, nutrient management plays an important role for good growth and flower production. The deficiency of nutrient in the soil is generally expressed in the form of certain disorders on the plant. The deficiency problems are particularly severe in light sandy soil which can be corrected by the additional supply of the particular nutrient to the plant. It has been observed that N, P, K and $\mathrm{Fe}$ nutrients are limiting factors in successful growing of golden rod.

Thus, the response of golden rod to the applied nutrients is quite encouraging in term of flower (panicles) production. Considering this, the present investigation was planned to find out the influence of chemical fertilizers on growth and flower production of golden rod. Considering the importance and increasing popularity of the golden rod domestic market, it is felt important to study the performance of the crop under different levels of nitrogen, phosphorus and potassium doses in order to find out the optimum values. Keeping these facts in view, the present study is proposed with the following objectives.

\section{RESEARCH METHODS}

The present investigation was carried out during Rabi season 2019-2020 at experimental field, Department of Horticulture, Naini Agriculture Institute, Sam Higginbottom University of Agriculture, Technology and Sciences, Prayagraj (U.P.), India. Prayagraj has a subtropical and semi-arid climatic condition, south-eastern part of Uttar Pradesh and 98 meter above the sea level the temperature falls down as low as $4-5^{\circ} \mathrm{C}$ during winter the average rainfall in this area is around during winter season especially in the month of December and January the average rainfall in this area is around $103.4 \mathrm{~mm}$ annually with maximum concentration during July to September with few showers and drizzles in winter also. The experiment was laid out in Randomized Block Design with three replications and 12 treatments.

For growth and floral attributes, Height of plant was recorded from the ground to the tip of the youngest leaf with the help of wooden scale and the mean height was expressed in centimeters at each stage. The spread of plant at 30, 60 and 90 days after planting was recorded. The spread was measured in North-South and East-West directions and their mean was taken for recording spread of plant in $\mathrm{cm}^{2}$. Number of stalk per plant was calculated by the mean taken from 2 plants per plot and it was calculated. The number of days taken for 50 per cent of the plants in any plot that received a particular treatment to produce panicles was recorded. Number of days 
required for all the plants in plot to produce panicles from the day of planting was recorded in each plot and their mean was worked out. Length of inflorescence was measured from the base of the inflorescence where the branches with fully opened florets arise, to the top most floret located on the bloom. Weight of the stalk was calculated by taking the weight of stalk after harvesting in which mean of 2 plants per plot was taken and calculated. One fourth opened compound flower blooms having uniform thickness and of $40 \mathrm{~cm}$ length were selected randomly from each treatment and used for the study. Lower leaves were removed and one panicle was kept in $250 \mathrm{ml}$ conical flask containing $200 \mathrm{ml}$ distilled water and another vase life was calculated when kept in 2 per cent sugar solution. Number of days was counted till the day on which panicles were found unfit for continuing in the vase and recorded as vase life.

In order to evaluate the economics of different treatments and to ascertain the most remunerative treatments, the expenses incurred on all cultural operations right from preparation of land to harvesting of the crop including as cost of inputs, viz., fertilizers, irrigation applied to each treatments were computed and added. The gross realization was worked out on the basis of mean no. Of flower yield per hectare of each treatment and the prevailing market price of golden rod cut flowers. The flowers were valued according to their grades (stems with a length of $40 \mathrm{~cm}$ and above were in grade I and those with below $40 \mathrm{~cm}$ length were in grade II). Grade I stems were valued at rupees 25/- each whereas, grade II stems were valued at rupees $20 /-$ each. The net realization per hectare was calculated by deducting the cost of cultivation from the gross realization for each treatment and recorded accordingly.

The data from the experiments were analyzed statistically, wherever treatment differences were found significant, the critical differences were worked out at 5 per cent level of probability $(\mathrm{P}=0.05)$.

\section{RESEARCH FINDINGS AND DISCUSSION}

The results obtained from the present investigation as well as relevant discussion have been summarized under following heads :

\section{Growth parameters:}

Plant height best result was shown in the $\mathrm{T}_{4}$ treatment in which N: P: K -75:120:90 kg/ha it showed the best height shown that was recorded.

Plant spread is also shown significant variations among the graded levels of nitrogen, phosphorus, potassium and their interactions at various stages of growth. The best result was shown in the $\mathrm{T}_{4}$ treatment in which $\mathrm{N}: \mathrm{P}: \mathrm{K}-75: 120: 90 \mathrm{~kg} / \mathrm{ha}$ it showed the best plant spread (E-W).

Plant spread is also shown significant variations among the graded levels of nitrogen, phosphorus,

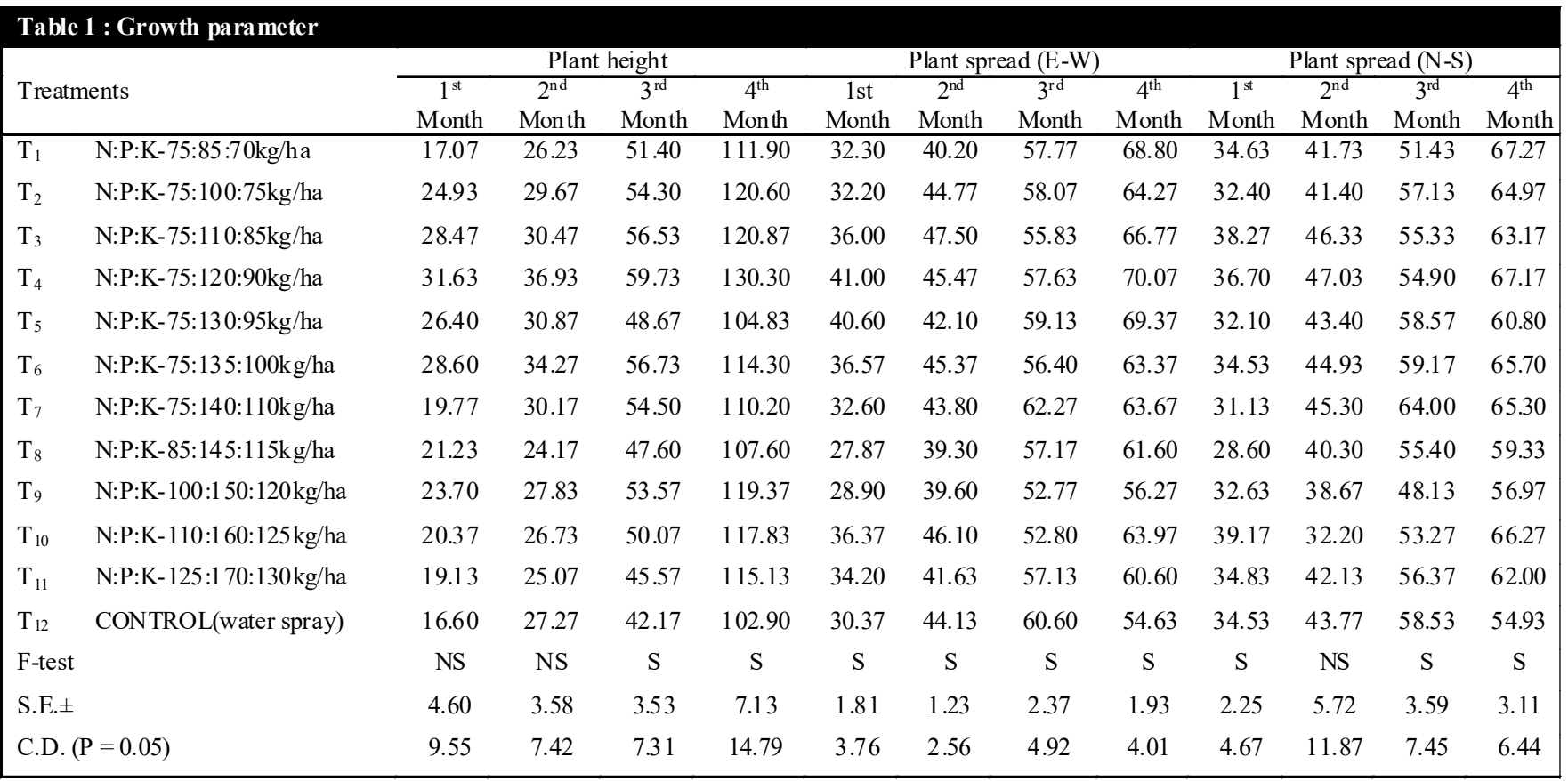




\begin{tabular}{|c|c|c|c|c|c|c|c|c|}
\hline $\begin{array}{l}\text { Sr. } \\
\text { No. }\end{array}$ & Treatments & $\begin{array}{c}\text { No. of } \\
\text { stocks/plant }\end{array}$ & $\begin{array}{l}\text { Length of the } \\
\text { stock }\end{array}$ & $\begin{array}{l}\text { Weight of } \\
\text { the stock }\end{array}$ & $\begin{array}{c}\text { No. of days } \\
\text { for } 50 \% \\
\text { flowering }\end{array}$ & $\begin{array}{l}\text { No. of days } \\
\text { for } 100 \% \\
\text { flowering }\end{array}$ & $\begin{array}{c}\text { Vase life } \\
\text { when kept in } \\
\text { water (days) }\end{array}$ & $\begin{array}{c}\text { Vase life of stock } \\
\text { when kept in } 2 \% \\
\text { sugar solution } \\
\text { (days) }\end{array}$ \\
\hline 1. & $\mathrm{~N}: \mathrm{P}: \mathrm{K}-75: 85: 70 \mathrm{~kg} / \mathrm{ha}$ & 13.33 & 38.70 & 51.97 & 90.00 & 120.00 & 7.67 & 8.67 \\
\hline 2. & $\mathrm{~N}: P: K-75: 100: 75 \mathrm{~kg} / \mathrm{ha}$ & 10.67 & 42.57 & 51.90 & 84.00 & 114.67 & 8.33 & 9.33 \\
\hline 3. & $\mathrm{~N}: \mathrm{P}: \mathrm{K}-75: 110: 85 \mathrm{~kg} / \mathrm{ha}$ & 12.00 & 42.57 & 51.60 & 83.00 & 117.00 & 8.67 & 9.33 \\
\hline 4. & $\mathrm{~N}: P: K-75: 120: 90 \mathrm{~kg} / \mathrm{ha}$ & 15.67 & 44.13 & 56.10 & 82.33 & 113.00 & 10.00 & 11.67 \\
\hline 5. & $\mathrm{~N}: \mathrm{P}: \mathrm{K}-75: 130: 95 \mathrm{~kg} / \mathrm{ha}$ & 13.67 & 43.17 & 55.63 & 85.33 & 117.67 & 9.00 & 10.00 \\
\hline 6. & N:P:K-75:135:100kgha & 11.67 & 43.90 & 52.17 & 86.67 & 117.67 & 8.00 & 11.00 \\
\hline 7. & $\mathrm{~N}: \mathrm{P}: \mathrm{K}-75: 140: 110 \mathrm{~kg} / \mathrm{ha}$ & 13.67 & 41.20 & 52.37 & 91.33 & 123.33 & 8.00 & 9.33 \\
\hline 8. & N:P:K-85:145:115kg/ha & 12.33 & 42.03 & 48.87 & 85.33 & 117.67 & 7.00 & 9.00 \\
\hline 9. & $\mathrm{~N}: \mathrm{P}: \mathrm{K}-100: 150: 120 \mathrm{~kg} / \mathrm{ha}$ & 10.33 & 40.27 & 50.07 & 89.67 & 120.00 & 8.00 & 10.33 \\
\hline 10. & N:P:K-110:160:125kg/ha & 11.00 & 39.80 & 50.40 & 93.00 & 123.67 & 7.00 & 9.00 \\
\hline 11. & N:P:K-125:170:130kg/ha & 13.33 & 41.67 & 50.73 & 93.00 & 121.33 & 9.00 & 10.33 \\
\hline \multirow[t]{4}{*}{12.} & CONTROL(water spray) & 10.33 & 38.57 & 48.90 & 95.00 & 124.67 & 6.33 & 7.33 \\
\hline & F-test & $\mathrm{S}$ & $\mathrm{S}$ & $\mathrm{S}$ & $\mathrm{S}$ & $\mathrm{S}$ & $\mathrm{S}$ & $\mathrm{S}$ \\
\hline & S.E. \pm & 0.99 & 1.24 & 1.31 & 2.07 & 1.83 & 0.55 & 0.69 \\
\hline & C.D. $(P=0.05)$ & 2.06 & 2.56 & 2.72 & 4.29 & 3.79 & 1.14 & 1.43 \\
\hline
\end{tabular}

potassium and their interactions at various stages of growth. The best growth was shown in $\mathrm{T}_{4}$ treatment in which N:P: K -75:120:90 kg/ha it showed the best plant spread (N-S).

\section{Floral parameters:}

The highest number of stalks per plant was shown in the treatment $\mathrm{T}_{5}$ that is $\mathrm{N}: \mathrm{P}: \mathrm{K}$ 75:130:90 has recorded the maxi-mum number of stalks per plant 15.67.

The highest length of the stock was shown in the treatment $\mathrm{T}_{4}$ that is $\mathrm{N}$ : P: $\mathrm{K}$ 75:120:90 has recorded the maximum stalk length $44.13 \mathrm{~cm}$.

The maximum weight of the stalk was shown in the treatment $\mathrm{T}_{5}$ that is $\mathrm{N}: \mathrm{P}: \mathrm{K}$ 75:130:90 has recorded the maximum weight of the stalk $56.10 \mathrm{~g}$.

The minimum days taken for 50 per cent flowering was shown in the treatment $\mathrm{T}_{4}$ that is $75: 120: 90$ has recorded 82.33 days and maximum days taken for 50 per cent flowering was shown in treatment $\mathrm{T}_{12}$ control (Water) recorded 95 days.

The minimum days taken for 100 per cent flowering was shown in the treatment $T_{4}$ that is 75:120:90 has recorded 113 days and maximum days taken for 100 per cent flowing were shown in treatment $\mathrm{T}_{12}$ (Water) recorded 124.67 days.

The maximum vase life was shown in the treatment $\mathrm{T}_{4}$ that is $\mathrm{N}$ : $\mathrm{P}: \mathrm{K}$ 75:120:90 10 days.
The maximum vase life when kept in 2 per cent sugar solution was shown in the treatment $\mathrm{T}_{4}$ that is $\mathrm{N}$ : P: K 75:120:90 11 days.

\section{REFERENCES}

Barad, A.V., Revar, H. J. and Rajput, S. T. (2011). Effect of nitrogen levels and cuttings (main and ratoon) on golden rod (Solidago canadensis L.) during summer and rainy season planting. Indian J. Hort., 68 (3): 379-3 85.

Chadha, A.P. S., Rathore, N.K. and Ganesh, R.K. (1999). Influence of $\mathrm{N}$ and $\mathrm{P}$ fertilization and ascorbic acid on growth and flowering of African marigold (Tagetes erecta L.). South Indian Hort., 47(1/6): $342-344$.

Gaikwad, S. A., Patil, S.S.D. and Patil, G. D. (2004). Effect of different levels of nitrogen and phosphorus on the growth and flower production of China aster (Callistephus chinensis L.) J. Maharastra Agric. Univ., 29 (2): 140-142.

Kokate, Shilpa, Chopda, Neha, Thakre and Seema (2011). Effect of nitrogen and potassium on growth, flower yield and quality of golden rod. Asian J. Hort., 6 (2) : $327-330$.

Lale, S. R., Kawarkhe, V. J., Jane, R. N. and Muradi, B. M. (2003). Effect of nitrogen and phosphorus levels on growth and yield of golden rod. Orissa J. Hort., 31(2): 24-28.

Naidu, J., Haritha, Ashok, P., Sekhar, Chandra, R. and Sasikala, K. (2014). Effect of plant growth retardants and spacings on vegetative growth and flower yield of African marigold (Tagetes erecta L.) cv. Pusa Narangi Gainda. Internat. 
J. Farm Sci., 4 (2) : $92-99$.

Patel, K. A. (2005). Influence of organic manures and chemical fertilizers on growth and flower production in golden rod (Solidago canadensis L.) cv. Local yellow under South Gujarat conditions. M.Sc. (Ag.) Thesis, Navsari Agricultural University, Navsari, Gujarat (India).

Pushkar, N. C., Rathore, S. V. S. and Upadhayay, D. K. (2008). Response of chemical and biofertilizer on growth and yield of African marigold (Tagetes erecta L.) cv. Pusa Narangi Gainda. Asian J. Hort., 3 (1) : 130 - 132.

Rajput, S. T., Rajput, S. G., Barad, A. V. and Bhamare, S. P. (2014). Effect of nitrogen levels on golden rod (Solidago canadensis L.). Bioinfoletion, 11(1B): 201 -203. phosphorus and potassium on growth and yield of golden rod (Solidago canadensis L.) cv. LOCAL Internat. J. Agric. Sci., 11 (1) : $108-111$.

Sharma, D. P., Patel, M. and Gupta, N. (2006). Influence of nitrogen, phosphorus and pinching on vegetative growth and floral attributes in African marigold (Tagetes erecta L.). $J$. Ornamental Horticulture, 9 (1): 25 - 28.

Singh, K. P. and Sangama (2000). Effect of graded level of N and $\mathrm{P}$ on china aster cultivar Kamini. Indian J. Hort., 57 (1): 87 -89 .

Sodha, B. P. and Dhaduk, B. K. (2002). Effect of spacing and nitrogen on Solidago (Golden rod). J.Ornamental Horticulture, 5 (1) : $63-64$.

Savaliya, A.B. and Vala, J.D. (2015). Effect of nitrogen, 